\title{
EFEKTIFITAS PENEGAKAN HUKUM TERHADAP TINDAK PIDANA PENANGKAPAN IKAN YANG MENGGUNAKAN BAHAN PELEDAK DI TAMAN NASIONAL WAKATOBI
}

\author{
Isro Daeng Halim \\ Mahasiswa Program Pascasarjana Universitas Muslim Indonesia Makassar \\ email : isro.daenghalim@ymail.com
}

\begin{abstract}
Law enforcement on Crime of Fish Catching Using explosives in TNW is still less effective, although it has been handled seriously by law enforcement officers in the form of preventative or repressive measures. This is due to several factors influencing the effectiveness of law enforcement on the crime of fishing using explosives in Waktatobi National Park are legal factors, law enforcement factors, facilities and infrastructure factors, legal awareness factors, and cultural factors.
\end{abstract}

Keywords: Law Enforcement; Fishing; Explosives;

\section{Abstrak}

Penegakan hukum tentang Kejahatan Penangkapan Ikan Menggunakan bahan peledak di TNW masih kurang efektif, meskipun telah ditangani secara serius oleh petugas penegak hukum dalam bentuk tindakan pencegahan atau penindasan. Hal ini disebabkan beberapa faktor yang mempengaruhi keefektifan penegakan hukum terhadap kejahatan penangkapan ikan menggunakan bahan peledak di Taman Nasional Waktatobi adalah faktor hukum, faktor penegakan hukum, faktor sarana dan prasarana, faktor kesadaran hukum, dan faktor budaya.

Kata kunci: Penegakan Hukum; Memancing; Bahan Peledak;

\section{A. PENGANTAR}

Dalam Pasal 1 ayat (3) Undang-Undang Dasar Negara Republik Indonesia Tahun 1945, ditentukan bahwa Negara Indonesia adalah Negara hukum. Penegasan ini, menjadi indikator bahwa setiap pelanggaran atau kejahatan yang terjadi harus ditindak sesuai hukum yang berlaku, apalagi suatu perbuatan hukum yang dilakukan, dapat mengancam jiwa diri sendiri, orang lain dan mengancam kelangsungan hidup sumber daya alam hayati yang dapat dimanfaatkan oleh manusia secara berkesinambungan.

Salah satu bentuk perbuatan manusia tersebut, adalah melakukan penangkapan ikan dengan menggunakan bahan peledak yang dapat mengakibatkan kerusakan terumbu karang, dan ikan yang belum saatnya ditangkap untuk dikonsumsi, serta biota laut lainnya yang dilindungi. Penangkapan ikan dengan menggunakan bahan peledak di Kawasan TNW adalah perbuatan pidana karena melanggar Pasal 1 ayat (1) Undang- Undang Darurat No. 12/Drt/1951 tentang Senjata Api, dan Pasal 33 ayat (1) dan ayat (3) Undang-Undang No. 5 Tahun 1990 tentang Konservasi Sumber Daya Alam Hayati dan Ekosistemnya. 
Sehubungan dengan tindak pidana kejahatan atau pelanggaran yang terjadi di TNW, maka aparat penegak hukum telah melakukan serangkaian kegiatan penyelesaian perkara sejak penyidikan oleh pihak penyidik kepolisian Republik Indonesia, atau pejabat pegawai negeri sipil yang diberi wewenang oleh Undang-Undang, penuntutan oleh jaksa penuntut umun hingga penjatuhan hukuman oleh hakim.Namun masih sering terjadi terdakwa dijatuhi hukuman yang ringan, sehingga tidak menimbulkan efek jera dan mereka cenderung melakukan perbuatan lagi dengan modus operandi yang sama.

Penggunaan bom dalam penangkapan ikan, adalah merupakan salah satu cara penangkapan yang sangat merusak dan juga ilegal di Indonesia. Pelaku yang melakukan penangkapan ikan dengan menggunakan bahan peledak tersebut, hanya mengumpulkan ikan konsumsi yang berharga saja, tetapi banyak ikan dan hewan laut lainnya ditinggalkan dalam keadaan mati di antara pecahan karang yang mungkin tidak akan pulih kembali.

Penggunaan bahan peledak dalam menangkap ikan adalah tindakan yang sangat merusak lingkungan, karena penggunaan bahan peledak dalam melakukan penangkapan ikan dapat menyebabkan rusaknya koloni karang yang ada di sekitar lokasi ledakan, dan dapat menyebabkan kematian organisme lain yang bukan menjadi target penangkapan. Hal ini dilakukan karena bahan baku untuk membuat bahan peledak tidak terlalu sulit diperoleh. Proses pembuatannya cukup sederhana dan jumlah tangkapan ikan lebih banyak dalam waktu yang singkat.

Berdasarkan informasi dari pihak Balai Taman Nasional Wakatobi dan Polres wakatobi bahwa di sekitar kawasan Konsevasi Taman Nasional Wakatobi masih ada nelayan tertentu yang melakukan Destruktif Fishing, baik yang menggunakan potasium sianida maupun yang menggunakan bahan peledak. Penggunaan potasium sianida maupun bahan peledak untuk menangkap ikan oleh nelayan setempat dilakukan secara sembunyisembunyi pada areal pantai yang jauh dari pemukiman untuk menghindari petugas Balai Taman Nasional Wakatobi, maupun pihak kepolisian resor wakatobi, meskipun upaya pencegahan yang dilakukan oleh aparat penegak hukum sudah optimal.

Secara empirik kerusakan yang terjadi mencapai $26,15 \%$ untuk kategori Hard Coral dan 30,06 \% untuk kategori Solt Coral yang dianggap rusak.Karena itu, sangat urgen untuk dilakukan penelitian tentang Destruktif Fising, khususnya tentang tindak pidana penangkapan ikan yang menggunakan bahan peledak di Taman Nasional Wakatobi.

\section{B. ANALISIS DAN PEMBAHASAN}

\section{Efektifitas Penegakan Hukum Terhadap Tindak Pidana Penangkapan Ikan Yang Menggunakan Bahan Peledak di Taman Nasional Wakatobi}

\section{a. Tindakan Preventif Polisi Kehutanan Mengantisipasi meningkatnya jumlah penggunaan bahan peledak di Kawasan Taman Nasional Wakatobi}

Polisi Kehutanan sebagai pejabat fungsional aparat kepolisian 
khusus, merupakan ujung tombak Kementerian Kehutanan dan bersamasama dengan instansi terkait lainnya,termasuk pelibatan masyarakat telah berupaya untuk mencegahterjadinya kerusakan terumbu karang dan biota laut lainnya akibatpenggunaan bahan peledak tersebut.

Tindakan atau wewenang yang dapat dilakukan oleh Polisi Kehutanan Balai Taman Nasional Wakatobi dalam upaya mencegah dan menanggulangi terjadinya ancaman, atau gangguan terhadap kawasan Taman Nasional Wakatobi, dikemukakan oleh Kepala seksi Pengelolaan Taman Nasional Wilayah II BTNW DI Kaledupa, La Fasa, bahwa kegiatankegiatan yang dilakukan tersebut meliputi sebagai berikut :

a. Operasi Intelijen dilaksanakan sebanyak 4 (empat) kali pertriwulan;

b. Operasi Fungsionaldilaksanakan sebanyak 3 (tiga) kali;

c. Operasi gabungandilaksanakan sebanyak 3 (tiga) kali;

d. Operasi Rutin dilakukan sebanyak 12 (dua belas) kali/setiap bulan.

- Patroli Mendadak / Insidentil sebanyak 2 (dua) kali;

- Proses Penyelesaian/ penanganan Kasus Hukum/Perkara.

Adapun latar belakang terjadinya kasus penggunaan bahan peledak di Kawasan Taman Nasional Wakatobi, menurutLaFasa bahwa Pelaku penyalahgunaan bahan peledak ini umumnya, adalah nelayan masyarakat pesisir Wakatobi dan nelayan luar Wakatobi, yang ingin mempunyai hasil tangkapan ikan yang lebih cepat dan banyak. Tanpa disadari oleh mereka, kegiatan ini sangat merusak ekosistem terumbu karang dan dampaknya kepada masyarakat itu sendiri.Penangkapan ikan dengan menggunakan bahan peledak pada kawasan perairan Taman Nasional Wakatobi dapat mengakibatkan kerusakan ekosistem bawah laut di area pemboman seperti hancurnya ekosistem terumbu karang sebagai habitat hidup ikan. Penggunaan bahan peledak tersebut juga akan mengakibatkan ikan dan satwa laut di area itu akan mati serta kondisi terumbu karang akan hancur.Untuk memulihkan kondisi terumbu karang pada keadaan semula sangat sulit karena karang telah dibom menjadi hancur bahkan terdapat beberapa lokasi menjadi berpasir.penggunaan bahan peledak dalam penangkapan ikan berdampak pada kerusakan karang, dengan bobot 0,5 $\mathrm{kg}$ bahan peledak mengakibatkan dalam radius 10 meter ikan akan mati dan radius 3 meter karang akan hancur". (wawancara tanggal 8 Agustus 2017).

\section{b. Tindakan Represif Penyidik POLRI}

Untuk mencegah atau menanggulangiterjadinya kegiatan menangkap ikan dengan menggunakan bahan peledak di TNW.Polres Wakatobi bersamainstansi terkait lainnya termasuk Polisi Kehutanan BalaiTNW, senantiasa berusaha untuk mengawasi dan mengamankan kawasan TNW, namun seringmengalami kesulitansaat melakukan mencari informasi dari masyarakat tentang adanya kemungkinan terjadi kegiatan penggunaan bahan peledak, atau saat akan mengadakanoperasi pengamanan Kawasan terhadap penggunaan bahan peledak,baik patroli mendadak maupun terencana (operasi gabungan) karena terbatasnya biaya operasional. 
Dalam kaitan ini, menurut Kasad Polair Polres Wakatobi, Iptu Idrus Unga bahwa Kami selalu berusaha memperbanyak informasi dari masyarakat nelayan yang difungsikan sebagai informan guna mengetahui adanya suatu peristiwa yang mungkin akan terjadi atau peristiwa yang telah terjadi. Polri juga senantiasa melakukan tindakan yang bersifat preventif dan represif, baik yang dilakukan secara internal Kepolisian maupun secara terpadu dengan pihak terkait lainnya. Sedangkan jenis kegiatan operasi internal yang dilakukan oleh Kepolisian Resor Wakatobi adalah operasi terpusat atau atas perintah.Namun demikian, ada suatu hal yang menjadi kendala Polair Polres Wakatobi dalam menjalankan tugas, yaitu dalam melakukan patroli rutin setiap bulan yang dilakukan oleh Polair Polres Wakatobi ada kendala yang dihadapi,dimana jumlah personil Polair Polres Wakatobi yang terdiri dari 10 orang personil, dan 2 buah kapal Speed Boat sudah di anggap cukup,namun operasional berupa bahan bakar yang disediakan sangatlah terbatas.Dimana Estimasi bahan bakar yang seharusnya di butuhkan 3 ton dalam sebulan,namun hanya 700 liter perbulan yang disediakan, sehingga dalam melakukan patroli rutin hanya disesuaikan dengan bahan bakar yang tersedia. (wawancara tanggal 3 Agustus 2017).

Sehubungan dengan penjatuhan hukuman oleh Hakim, menurut Idrus Ungabahwa Polisi sebagai penyelidik dan penyidik telah berusaha semaksimal mungkin dalam melaksanakan tugas tersebut, sampai akhirnya kasus itu dilimpahkan ke kejaksaan dengan maksud untuk digelar di pengadilan.Namun melihat beberapa kali putusan pengadilan atas perkara penyalahgunaan bahan peledak di Wakatobi, dengan penjatuhan hukumannya terlalu ringan, atau jauh berbeda dengan ancaman hukuman atas perbuatan tersebut, yang sudah tentu tidak seimbang dengan akibat dari perbuatan itu, yaitu kerusakan terumbu karang yang menyangkut hajat hidup orang banyak dan tenaga, serta biaya yang dikeluarkan saat melakukan kegiatan operasi pengamanan, penangkapan dan proses perkara, hingga ke tingkat penyerahan berkas perkara, tersangka dan barang bukti. Karena itu, Kepolisian sangat berharap semoga hukuman yang dijatuhkan kepada pelaku harus setimpal dengan akibat perbuatan yang ia lakukan. (wawancara tanggal 3 Agustus 2017).

\section{c. Dakwaan Jaksa Penuntut Umum dan pelaksanaan putusan pengadilan yang telah memperoleh kekuatan hukum tetap}

Menurut A.Agung G.A. Kusuma Putra selaku Jaksa fungsional pada kejaksaan Negeri Wakatobi bahwa Dakwaan yang dilakukan oleh JPU kepada terdakwa dalam persidangan sesuai tindak pidana (modus operandi) yang dilakukan terdakwa, jenis pelanggaran atau kejahatan yang telah dilakukan oleh terdakwa. (Wawancara 18 Agustus 2017) .

Penuntutan hukuman yang diajukan oleh Jaksa Penuntut Umum di Pengadilansesuai keterangan para saksi dan keterangan terdakwa telah memenuhi unsur-unsur tindak pidana, dan dijadikan pertimbangan untuk menjatuhkan hukuman yang pantas dijatuhkan kepada terdakwa. Dengan demikian dakwaan dan tuntutan yang diajukan JPUmenjadi salah satu bahan pertimbangan Hakim untuk menjatuhkan hukuman kepada terdakwa atas perkara penyalahgunaan bahan peledak di TNW yang telah

Al-Ishlah: Vol.21 No.2 November 2019 
berdampak kepada masyarakat pesisir atau pengguna sumber daya alam dan berbagai sektor pembangunan baik Nasional maupun Daerah.

\section{d. Penjatuhan Hukuman olehHakim di Pengadilan Negeri Klas 1B Baubau}

Putusan Hakim dalam menjatuhkan hukuman tidak jauh berbeda dengan tuntutan JPUKejaksaan Negeri Baubau. Dalam kaitan ini,menurut Hairuddin Tomu selakuhakim Pengadilan Negeri Baubau bahwa dalam menjatuhkan hukuman terhadap pelaku tindak pidana penangkapan ikan yang menggunakan bahan peledak,Hakim tidak serta merta mengacu pada tuntutanJPU, namun ada beberapa hal yang menjadi pertimbangan Hakimdalam menjatuhkan vonis terhadap terdakwa, melainkan hakim akan menganalisa tentang semua fakta-fakta dalam persidangan baik dari objek maupun subjeknya. (wawancara tanggal 18 Agustus 2017).

Hakim dalam menjatuhkan pidana kepada terdakwa, harus didukung sekurang-kurangnya 2 (dua) alat bukti yang sah dan ia memperoleh keyakinan bahwa suatu tindak pidana benar-benar terjadi dan terdakwalah yang bersalah melakukannya. Alat bukti yang sah dimaksud adalah keterangan saksi, keterangan ahli, surat, petunjuk dan keterangan terdakwa.Mengenai pidana yang dijatuhkan oleh majelis Hakim Pengadilan Negeri Baubau bukanlah suatu tindakan balas dendam, melainkan sematamata untuk membuat sadar para pelaku, dan jika kembali ke tengah-tengah masyarakat tidak akan mengulangi lagi perbuatannya. Dengan demikian penegakan hukum yang dilaksanakan oleh aparat penegak hukum, baik dari pihak Polhut, POLRI, Jaksa maupun Hakim terhadap tindak pidana penangkapan ikan yang menggunakan bahan peledak di Taman Nasional Wakatobi kurang terlaksana secara efektif.

\section{Faktor-faktor Yang Mempengaruhi Efektifitas Penegakan Hukum Terhadap Tindak Piidana Penangkapan Ikan Yang Menggunakan Bahan Peledak di Taman Nasional Wakatobi}

Dalam konteks penegakan hukumterdapat berbagai indikator untuk menentukan efektif tidaknya pelaksanaan hukum dalam realitasnya.Demikian pula dengan penegakan hukum terhadap tindak pidana penangkapan ikan yang menggunakan bahan peledak di Taman Nasional Wakatobi, tidak terlepas dari adanya beberapa faktor yang pengaruh. Adapun faktor-faktor yang berpengaruh tersebut, adalah :

\section{a. Faktor Hukum}

Dalam UU No. 5 Tahun 1990 ditentukan bahwa taman nasional dikelola dengan sistem zonasi yang terdiri dari zona inti, zona pemanfaatan dan zona lain sesuai dengan keperluan. Dari data penanganan kasus Tindak Pidana Konservasi Sumber Daya Alam Hayati dan Ekosistemnya dan Bahan Peledak di Taman Nasional Wakatobi,ditemukan kasus penangkapan ikan yang menggunakan bahan peledak, pelaku hanya divonis dengan sanksi pidana penjara paling lama 1 (satu) tahun 4(bulan) bulan dan denda paling banyak 
Rp.5.000.000,- (lima juta rupiah), dengan ketentuan apabila denda tersebut tidak dibayar oleh terdakwa, maka diganti dengan hukuman kurungan selama 1 (satu) bulan kurungan.Sanksi yang dijatuhkan sangat ringan, jika dibandingkan dengan ancaman hukuman yang ditentukan dalam UU No.12/Drt/ Tahun 1951tentang Bahan Peledak dan Senjata Api dan UU No. 5 Tahun 1990, yaitu ancaman hukum penjara paling lama 5 (lima) tahun dan denda paling banyak Rp. 100.000.000,(seratus juta rupiah).

Kasus penangkapan ikan yang menggunakan bahan peledak di Wilayah Konservasi TNW merupakan kegiatan atau perbuatan yang tidak sesuai dengan fungsi zona pemanfaatan dan zona lainnya di taman nasional, namun dalam implementasi penegakan hukum ketentuan ini masih sulit diterapkan.

\section{b. Faktor Penegak Hukum}

Kawasan TNWmemiliki luas1.390.000, (satu juta tiga ratus ribu) ha. Saat ini jumlah personil atau aparat yang melakukan tugas pengamanan dan perlindungan kawasan terdiri dari 21 personil Polisi kehutanan, 2 (dua) orang berkualifikasi sebagai PPNS ditambah 3 (tiga) orang PPNS Kehutanan dari non Polhut, yakni Kepala Balai TNW, Kepala SPTN Wil. I dan 1 (satu) orang staf Balai TNW.Personil Polisi Kehutanan tersebar di tiga wilayah SPTN, masing-masing SPTN Wil I berjumlah 8 (delapan) orang, SPTN Wil. II berjumlah, 7 (tujuh) orang dan SPTN Wil.III berjumlah 6 (enam) orang.

Dilihat dari segi kuantitas atau jumlah aparat penegak hukum di Balai Taman Nasional Wakatobi khususnya Polisi kehutanan dan PPNS, data yang ada jumlah keduanya sangat minim dan sangat tidak sesuai dengan luas kawasan Taman Nasional Wakatobi yang harus di jaga. Sesuai dengan data kebutuhan formasi pegawai di Balai Taman Nasional Wakatobi sampai dengan Tahun 2016 untuk tenaga Polisi Kehutanan seharusnya berjumlah 50 (lima puluh) orang. Jika dirataratakan dengan pelaksanan tugas pengawasan oleh seorang petugas polhut, maka setiap petugas harus menjaga luas kawasan taman nasional seluas $\pm 66 \cdot 190,48$ ha. Hal ini tentunya sangat sulit dilaksanakan, maka wajar apabila pelaksanaan pengawasan dan pengamanan kawasan belum maksimal.

Dalam kaitan ini, menurut Amiluddin selaku personil Polhut SPTN Wil.III (wawancara tanggal 6Agustus 2017) bahwa kawasan yang kami jaga sangat luas tidak sebanding dengan jumlah Polhut di lapangan. Pelaksanaan kegiatan patroli dilakukan baik patroli pesisir maupun patroli perairan, karena luasnya wilayah yang harus di awasi sehingga sangat memerlukan dukungan sarana dan prasarana yang memadai.Karena personil kami terbatas, kegiatan patroli keamanan di kawasan tidak bisa rutin setiap saat.

Aparat penegak hukum merupakan salah satu faktor yang menyebabkan tegaknya hukum di bidang Konservasi Sumber Daya Alam Hayati dan Ekosistemnya di TNW.Namun demikian kenyataan menunjukkan jumlah penegak hukum yang kurang, kewenangan yang 
terbatas yang dimiliki oleh Polhut dan PPNS, perbedaan persepsi antar penegak hukum dalam penerapan undang-undang, kurangnya koordinasi dan rendahnya kualitas pemahaman aparat penegak hukum dalam penerapan UU No. 5 Tahun 1990.

Dilihat dari segi jumlah aparat penegak hukum di Balai TNW, khususnya Polisi kehutanan dan PPNS, sangat minim dan tidak sesuai dengan luas kawasan yang harus dijaga.Karena itu, diperlukan tambahan personil tenaga Polisi Kehutanan untuk menjaga kawasan TNW seluas 1.390 .000 ha.Sementara tenaga polhut yang ada hanya 21 orang, yang seharusnya paling tidak berjumlah 50 orang.

Keberadaan penyidik pegawai negeri sipil dalam sistem peradilan pidana berada dalam satu komponen yang sama dengan penyidik Polisi Republik Indonesia (Polri). Dalam UU No. 2 Tahun 2002 tentang Kepolisian RI, ditentukan bahwa Polri melakukan koordinasi, pengawasan dan pembinaan teknis terhadap PPNS. Sementara itu, didalam Undang-Undang Nomor 8 Tahun 1981 tentang KUHAP, keberadaan PPNS di atur dalam Pasal 6 ayat (1) huruf b, Pasal 7 ayat (2), Pasal 107 dan Pasal 109 KUHAP.

PPNS Kehutanan yang diberi kewenangan khusus melakukan tugas penyidikan di bidang konservasi sumber daya alam hayati dan ekosistemnya, memiliki kewenangan yang sangat terbatas tidak sama dengan kewenangan yang dimiliki oleh penyidik Polri. PPNS Kehutanan tidak memiliki kewenangan menangkap, menahan pelaku tindak pidana atau melakukan tindakan lain menurut hukum yang bertanggungjawab seperti penyidik Polri. PPNS Kehutanan didalam melaksanakan tugas penyidikan berada di bawah koordinasi dan pengawasan pejabat penyidik Polri, termasuk dalam hal menangkap dan menahan pelaku tindak pidana harus meminta bantuan dari pejabat penyidik Polri karena PPNS Kehutanan tidak memiliki kewenangan.

Di samping itu, PPNS Kehutanan juga tidak memiliki kewenangan untuk melakukan penyidikan pada tindak pidana bidang yang lain, seperti tindak pidana perikanan atau lingkungan hidup. Kewenangan PPNS Kehutanan sesuai dengan undang-undang hanya memiliki kewenangan menegakkan hukum khusus UU No. 5 Tahun 1990 dan UU No. 41 Tahun 1999 tentang Kehutanan. Kewenangan PPNS Kehutanan dalam 2 (dua) undang-undang tersebut, tidak mengadopsi ketentuanketentuan dasar kewenangan penyidik sesuai KUHAP, yang menyebabkan ketidakmandirian PPNS dalam melaksanakan tugas penyidikan.Keterbatasan kewenangan PPNS Kehutanan tersebut, merupakan salah satu faktor kelemahan penegakan hukum di bidang konservasi sumber daya alam hayati dan ekosistemnya di TNW.

\section{c. Faktor Sarana dan Prasarana}

Ketersediaan sarana dan prasarana yang cukup memadai akan mendukung pelaksanaan tugas di lapangan. Namun penegakan hukumterhadap kawasan TNW masih mengalami kendala, khususnya speed boatdan biaya operasional yang sangat mahal. Dalam sehari saja misalnya, untuk melakukan kegiatan patroli pengamanan kawasan TNW 
denganspeed boat memerlukan bahan bakar \pm 1.000 (seribu) liter bensin, atau sekitar 5 juta s.d 7 juta rupiah, sementara dana yang tersedia sangat terbatas, sehingga frekuensi patroli pengamanan kurang efektif. Disamping itu, penanganan kasus perkara pidana yang terjadi di kawasan perairan laut membutuhkan biaya yang mahal, terutama dalam hal pengamanan dan pengangkutan barang bukti tindak pidana.

Selain itu, kemampuan penguasaan teknologi khususnya perbaikan dan pemeliharaan armada/kendaraan laut, dibutuhkan personil yang memiliki kemampuan teknis di bidang perkapalan atau speed boat, sehingga ketika terjadi kerusakan dapat segera dilakukan perbaikan dan perawatan.Tanpa adanya sarana atau fasilitas pendukung tidak mungkin penegak hukum dapat melaksanakan tugas dan fungsinya dengan baik, terutama sarana fisik yang berfungsi sebagai faktor pendukung.Dari hasil penelitian menunjukkan bahwa sarana atau fasilitas pendukung pelaksanaan tugas penegakan hukum dilapangan menjadi faktor yang mempengaruhi lemahnya penegakan hukum tindak pidana di bidang Konservasi Sumber Daya Alam Hayati dan Ekosistemnya di TNW.

\section{d. Faktor Masyarakat}

Salah satu faktor yang mengefektifkan suatu peraturan atau hukum adalah berhubungan dengan kesadaran masyarakat untuk mematuhinya.Kepatuhan masyarakat terhadap hukum merupakan salah satu indikator berfungsinya hukum yang bersangkutan.

Hasil penelitian menunjukkan bahwa faktor yang terkait dengan masyarakat terhadap lemahnya penegakan hukum tindak pidana penggunaan bahan peledak, disebabkan oleh beberapa hal meliputi : faktor kemiskinan, pemahaman dan pengetahuan yang rendah, keterbatasan sarana usaha bagi nelayan, kebiasaan turun temurun dalam hal kegiatan penangkapan ikan di perairan kepulauan Wakatobi, tidak mengenal adanya sistem zonasi dan pengaruh godaan//pengaruh pengusaha dari luar wakatobi dengan pemberian fasilitas-fasilitas tertentu.

Untuk mencegah terjadinya tindak pidana, maka perlu ditingkatkan sosialisasi tentang kesadaran hukum masyarakat, dan pemberian sanksi yang tegas, baik itu pengusaha, pejabat, aparat penegak hukum maupun masyarakat harus benar-benar diterapkan, sehingga dapat membangun kepercayaan masyarakat terhadap aparat penegak hukum dalam penegakan hukum atas Undang-Undang khususnya UU No. 5 Tahun 1990 tentang Konservasi Sumber Daya Alam Hayati dan Ekosistemnya.

\section{e. Faktor Kebudayaan}

Pada dasarnya kebudayaan mencakup nilai-nilai yang mendasari hukum yang berlaku, nilai-nilai yang merupakan konsepsi-konsepsi abstrak mengenai apa yang dianggap baik (sehingga dianuti), dan apa yang dianggap buruk (sehingga dihindari). Nilai-nilai tersebut, lazimnya merupakan pasangan nilai-nilai yang mencerminkan dua keadaan 
ekstrim yang harus diserasikan.

Hasil penelitian menunjukkan bahwa faktor kebudayan yang terkait dengan faktor yang mempengaruhi lemahnya penegakan hukum tindak pidana di bidang Konservasi Sumber Daya Alam Hayati dan Ekosistemnya di TNW, meliputi nilai-nilai konservasi yang dianut atau prinsip yang berbeda antara masyarakat dengan peraturan perundangundangan yang berlaku. Faktor rendahnya pemahaman dan pengetahuan tentang pelestarian sumber daya alam, kewenangan pengelolaan sumber daya perairan laut beralih dari masyarakat dengan hukum adat, menjadi sepenuhnya kewenangan pemerintah.Oleh karena itu, perlu dilakukan inventarisasi, penggalian gagasan ide-ide lokal, kebiasaan masyarakat dalam melakukan pemanfaatan wilayah laut yang mendukung upaya konservasi.Pengelolaan kawasan konservasi laut harus dikaji dengan pendekatan berbagai aspek meliputi budaya masyarakat Indonesia, hasil-hasil kajian ilmiah atau penelitian ilmiah.dan aspirasi masyarakat setempat.

\section{PENUTUP}

Penegakan hukum terhadap Tindak Pidana Penangkapan Ikan yang Menggunakan bahan peledak di TNW masih kurang efektif, walaupun telah ditangani secara serius oleh aparat penegak hukum dalam bentuk tindakan yang sifatnya preventif maupunrepresif yang dilakukan Balai Taman Nasional Wakatobi dan Polres Wakatobi, penuntutan oleh Jaksa penuntut umum, sampai dengan vonis oleh pengadilan.Faktor-faktor yang mempengaruhi efektifitas penegakan hukum terhadap tindak pidana penangkapan ikan yang menggunakan bahan peledak di Taman Nasional Waktatobi,adalah faktor hukum, faktor penegak hukum, faktor sarana dan prasarana, faktor kesadaran hukum, dan faktor kebudayaan.

\section{DAFTAR PUSTAKA}

A. Hutabarat, 2003, Rangkuman Peraturan Perundang - undangan Kehutanandan Konservasi Sumber Daya Hayati dan Ekosistemnya,CV.Samudra Intan Rejeki,cet.1,Jakarta

Abdurrahman, 1990 .Pengantar Hukum Lingkungan I ndonesia. PT Citra Aditya bakti.Bandung.

Arief, Barda Nawawi, 2002, Bunga Rampai Kebijakan Hukum Pidana CitraAditya Bakti,Bandung.

Djasadin Saragih .1977. Hukum dan Masyarakat, Fakultas Hukum Unair Surabaya.

Husein, Harun M. 1995. Lingkungan Hidup (Masalah Pengelolaan dan Penegakan Hukumnya). Bumi Aksara, Jakarta.

Marlang, Abdullah. 1997, Penegakkan Hukum di Bidang Konservasi Sumber 
Daya Alam.(Desertasi). Program Pascasarjana Unhas. Makassar.

Said Sampara dan La Ode Husen, 2016. Metode Penelitian Hukum edisi revisi. Kretakupa.Makassar.

Soekanto, Soerjono.1982.Fungsi Hukum dan Perubahan Sosial.Alumni, Bandung.

---------, 1983.Faktor-Faktor Yang Mempengaruhi Penegakan Hukum.

Rajawali.Jakarta 